\title{
Prioritising Project Scope Definition Elements in Public Building Projects
}

Mohammed K. Fageha, Ajibade A. Aibinu (University of Melbourne, Australia)

\begin{abstract}
A complete definition of the scope of a project upfront during early stages ensures smooth and successful implementation during the project execution. This research identifies and prioritises project scope definition elements for public buildings in Saudi Arabia. Elements that could significantly contribute to complete project scope definition package at pre-project planning stage are identified and their interrelationship determined and prioritised. Using the Project Definition Rating Index (PDRI) as a basis, the study uses analytical network process (ANP) technique based on data obtained from project managers who have been involved in public sector projects in Saudi Arabia. Data collection and analysis was conducted in three steps. The first step involved identification of scope definition elements while the second involved an investigation into interrelationships among the elements. In the third step, ANP was used to determine the weight of the elements' importance in terms of contribution to project scope definition completeness. Finally, Pareto analysis was used to prioritise and assess the distribution pattern of the elements. The outcome from this research is the prioritisation of project scope definition elements for public building projects in Saudi Arabia. The prioritised list developed indicates the importance of project scope definition elements. It should help project management teams identify elements to consider when evaluating project scope definition for completeness at the pre-project planning stage.
\end{abstract}

Keywords: Project scope definition, pre-project planning, prioritising, public building projects, Saudi Arabia, Analytical Network Process (ANP)

\section{Introduction}

Project scope definition is the process whereby the work that is needed to produce a building is identified and described in sufficient detail to facilitate project execution. It gives the project team an understanding of what needs to be done while at the same time helping the team in setting up management control systems that can be applied during project execution; and could impact on project outcomes. In the construction industry, having a better project outcome is significant because construction is one of the most important sectors in many economies and a significant contributor to the gross domestic product (GDP) of most countries. This is especially valid in developing countries such as Saudi Arabia, where the construction industry is one of its largest. While the construction industry in Saudi Arabia contributes approximately $4.8 \%$ to the GDP and $9.4 \%$ of non-oil sectors, almost $30 \%$ of the non-oil sectors' activities occur in the public sector (Central Department of Information and Statistics 2013). Due to the importance of the construction sector, it is necessary to ensure that construction projects are completed successfully. However, the Saudi construction sector has been experiencing problems in productivity, innovation, schedule slippage, rework, mistakes and disputes, which have all increased construction costs (Abdul-Hadi, AlSudairi \& Alquahtani 2005). Project abandonments are very common and are often symptoms of failed processes in the early stages of a project. Purportedly, in 2011 there were around 2262 abandoned public building projects in the Makkah region, which is only one of the thirteen regions. Inadequate pre-project planning and poor definition of project elements have been identified as the major reasons for the problem (Al-Humaidan 2011). In fact, up to $70 \%$ of poor time performance in Saudi Arabian projects caused by changes in the project scope (Assaf \& Al-Hejji 2006; AlKharashi \& Skitmore 2009). Alsehaimi, Koskela and Tzortzopoulos (2013) investigated a number of studies on delay in construction projects in 
developing countries including Saudi Arabia. Their study cited poor project management as one of the main causes of delay. They reported that poor planning and control is, specifically, the factor that had been identified in most studies. The study concluded that action research is needed to generate practical managerial approaches to address delay issues and enhance project management practice in Saudi Arabia. This study contributes in the area of project scoping and project definition in the pre-project planning stage, which could remedy the problem if properly approached.

Most public sector projects in Saudi Arabia frequently rely on the traditional procurement method (also known as the design-bid-build method), where the client develops the business case, provides a brief, budget and tender document. Thereafter, the client appoints a design consultant in the design stage and a contractor through competitive bidding, in which the lowest bidder is awarded the contract (Hatush \& Skitmore 1998). One of the critical problems faced by government authorities is the frequent and lengthy delays in their projects (Al-Khalil \& Al-Ghafly 1999). Lengthy delays are often caused by a number of issues such as unqualified contractors, changes in the scope of work, rework and inappropriate parties involvement due to the procurement method (Assaf \& Al-Hejji 2006). Traditional procurement has been criticised due to the sequential approach to delivering a project (Love 2002). Love referred to the time gap between design and construction as 'procurement gap'. Changes and reworks may occur due to the time gap. In fact, Arain, Pheng \& Assaf (2006) identify that the inconsistencies between design and construction, which occur due to the procurement gap, have a significant impact on construction project performance in Saudi Arabia. In order to reduce these changes and reworks, the project scope should be well-defined at the preplanning stage of the project.

Inadequate pre-project planning and poor scope definition continue to emerge as major causes of expensive changes, delays, rework, cost overruns and schedule overruns, and they often lead to project failure (Mirza, Pourzolfgaghar \& Shahnazari 2013; Lordsleem Jr \& Melhado 2014). Changes during project execution often reflect the uncertainties that occur during the early stages of the project (Assaf \& Al-Hejji 2006). Changes are requested during the construction stage as a result of the differences in the perspectives that each stakeholder has on the project. The fundamental reason for such change in orders is either poor project definition, or poor idea of how the work has to be handled. Thus, defining the scope of a project at the early stage using input from all stakeholders is vital. The purpose of project scope definition is to generate adequate information that is needed to identify and describe the work to be performed, in order to avoid major changes that may negatively affect project outcome (Gibson et al. 2006). This information is needed before making the decision whether or not to proceed with the project execution (Kähkönen 1999). They also form the basis for project design and therefore project execution.

Lack of a clear project scope definition, as well as improper control of these, have been recognised by recent researchers as major barriers to project success (Mirza, Pourzolfgaghar \& Shahnazari 2013). Therefore, having a well-defined project during the preproject planning stage is crucial for success during project execution and for achieving a satisfactory project outcome. One of the first steps in the pre-project planning process is to understand what needs to be defined in order to ensure that project scope is clear upfront, thereby facilitating project success. Accordingly, the objectives of the study reported here are:

- To identify the elements that should be considered in defining public building projects in Saudi Arabia;

- To investigate the interrelationships among elements; and

- To determine the level of significance of each element in terms of their contribution to the overall project definition completeness.

Fageha, M.K \& Aibinu, A.A. 2014, 'Prioritising Project Scope Definition Elements in Public Building Projects', Australasian Journal of Construction Economics and Building, 14(3), 18-33. 


\section{Literature Review}

\section{Significance of Project Scope Definition}

The purpose of project definition is to provide adequate information that is needed to identify the work to be performed without major changes, and it may affect performance of a project (Chritamara, Ogunlana \& Bach 2001; Gibson et al. 2006). Success during detailed design and execution stage of a project is highly dependent on the level of effort expended during the scope definition stage. When a project proceeds to the implementation stages with inadequate definition of one or more project elements, it may be subjected to differing expectations and interpretation by different stakeholders (Atkinson et al. 2006). Thus, a poor definition of project scope can lead to dissatisfaction by project stakeholders, simply because their expectations have not been fulfilled (Cano \& Lidón 2011). It can also lead to design errors, owner changes and rework, which are often sources of schedule slippage and cost overruns (Love, Irani \& Edwards 2004; Hwang et al. 2009).

\section{Project Scope Definition and Pre-project Planning}

Construction projects procedures are conducted in the same manner, though each has its own characteristics. Different researchers classified the pre-project planning early phase into stages (Table 1). Despite the differences in classification, there is general agreement in the literature that project scope definition documentation should be developed prior to making the final decision on whether to proceed with the project or not. In order to make this decision, an evaluation of the completeness of the project scope definition document should be conducted. Therefore, knowing the significance of each element of the project scope definition document is important for the evaluation task, which is the purpose of this research.

Table 1: Stages within the pre-project planning phase

\begin{tabular}{|c|c|c|c|c|c|}
\hline \multirow{2}{*}{$\begin{array}{l}\text { Source } \\
\text { Gibson et al. } \\
\text { (1995) }\end{array}$} & \multicolumn{5}{|c|}{ Stages within the pre-project planning phase } \\
\hline & $\begin{array}{l}\text { Organise for pre- } \\
\text { project planning }\end{array}$ & $\begin{array}{l}\text { Select pr } \\
\text { alternati }\end{array}$ & $\begin{array}{l}\text { Dev } \\
\text { defi }\end{array}$ & $\begin{array}{l}\text { project } \\
\text { package }\end{array}$ & $\begin{array}{l}\text { Decide whether to } \\
\text { proceed with project }\end{array}$ \\
\hline Kähkönen (1999) & $\begin{array}{l}\text { Plan project } \\
\text { definition }\end{array}$ & $\begin{array}{l}\text { Generate and } \\
\text { analyse } \\
\text { alternatives }\end{array}$ & $\begin{array}{c}\text { Select } \\
\text { alternative(s) }\end{array}$ & $\begin{array}{l}\text { Prepare } \\
\text { documents }\end{array}$ & Decide on project \\
\hline Woodhead (2000) & Initial idea & Capital proposal & Outline case & Full case & Decision approval \\
\hline $\begin{array}{l}\text { Haponava and Al- } \\
\text { Jibouri (2009) }\end{array}$ & Initiative & & Feasibility & & Project definition \\
\hline
\end{tabular}

The Construction Industry Institute (CII) defined pre-project planning as "the process of developing sufficient strategic information with which owners can address risk and decide to commit resources to maximize the chance for a successful project" (CII 1994). Additionally, it is the process that combines all tasks between project initiation phase to the beginning of detailed design phase (Gibson et al. 2006). It begins with a project concept that reflects a business need and ends with a decision whether to proceed and start the execution of the project by developing the detailed design (Gibson, Kaczmarowski \& Lore 1995). Many experts and industry practitioners believe that pre-project planning efforts in the project life cycle have significantly greater impact on the whole project life cycle, thus improving project final outcomes. Specifically, Cho and Gibson (2001) studied project performances of 53 capital facility projects. They investigated the total cost, scheduling and operational characteristics, and then compared them to the effort spent on the pre-project planning. The study concluded that up to $20 \%$ of cost savings and $39 \%$ of schedule savings could occur when a high level of pre-project planning effort is implemented. Therefore, better pre-project planning stage has a greater influence on the project life cycle when its expenditure is low

Fageha, M.K \& Aibinu, A.A. 2014, 'Prioritising Project Scope Definition Elements in Public Building Projects', Australasian Journal of Construction Economics and Building, 14(3), 18-33. 
compared to the other stages. Prior to deciding on a project's implementation, scope definition is the last activity undertaken in the pre-project planning stage. Because of its importance, many studies have been conducted to find better approaches that can be adopted for defining and scoping a project.

\section{Approaches for Measuring the Project Scope Definition Completeness}

In order to improve project scope definition completeness, the Cll developed the Project Definition Rating Index (PDRI) (Wang 2002). PDRI is a scoring tool for measuring the adequacy of project scope definition and assessing pre-project planning effort. It is one of the most comprehensive and established tools for measuring project scope definition for completeness. When used, it allows the project team to take actions to improve the scope definition of those elements that have high scores, which indicate the areas of risk to the project (Gibson et al. 2006).

The PDRI started with a version that was designed specifically for industrial projects. After the success of PDRI for industrial projects, a similar tool was developed for buildings. The validation of PDRI on more than 190 projects with total estimated cost of more than $\$ 6.5$ billion dollars (Cho \& Gibson 2001; Wang \& Gibson 2010), shows that there is a positive relationship between PDRI score for a project with cost and time performances. PDRI for building consists of three sections, eleven categories and sixty-four elements. During the planning phase, the project team would pay special attention to these elements to reduce the uncertainties in the subsequent phases. In order to calculate the overall score of scope definition elements for the project, the project management team would evaluate the completeness level of each element's definition on the list. The maximum score is 1000 points, and the lower score represents a more complete and well-defined project (Cho \& Gibson 2001).

Construction organisations in Saudi Arabia lack a systematic approach for defining the project scope elements in the pre-project planning stage. Using a well-established list of project scope definition elements such as PDRI is a good approach. However, the PDRI was developed in the US and mainly for the same context. Even though the development process for construction projects may share the same procedure globally, it still requires a different set of information that respects the nature and the environment of the project. This study is focused on public building projects in Saudi Arabia. The differences between the two contexts could be from the tendering approach, project organisational structure or the allocation of responsibilities among a project's parties. Therefore, it is prudent to identify project scope definition elements and weights that are compatible with public building projects in the Saudi Arabian context. The current research uses the PDRI for building elements as a point of departure to develop a model for the Saudi Arabian public construction projects.

\section{Analytical Approach}

This research aims to develop an analytical decision-support model in the form of prioritised project scope definition elements, to assist public construction organisations in Saudi Arabia when assessing project scope defined for completeness. The study uses Analytical Network Process (ANP) approach. ANP is a developed version of what is known as AHP (Analytical Hierarchical Process). Saaty developed AHP as a decision-making technique used in the military for allocating resources and planning needs in the 1970s (Cheng \& Li 2001). He stated that AHP is a general theory of measurement (Saaty 1994). It is a technique that helps break down a complex, unstructured situation into its component parts in hierarchical structures. After launching the ANP in 1996, and due to its flexibility to solve complex forms of decision-making problems, AHP became a special case of ANP because it contains neither feedback nor loops within the same cluster representing inner dependence. Saaty (1996) defined ANP as a general theory of relative measurement used to derive composite

Fageha, M.K \& Aibinu, A.A. 2014, 'Prioritising Project Scope Definition Elements in Public Building Projects', Australasian Journal of Construction Economics and Building, 14(3), 18-33. 
priority ratio scales from individual ratio scales that represent relative measurements of the influence of elements that interact with respect to control criteria. By replacing the hierarchies with networks, ANP has been widely used as a multi criteria decision-making tool, instead of AHP. AHP is a technique that constructs a problem into several levels in a form of hierarchy and each element is independent (Saaty 1994). However, ANP can be used as an effective tool in cases where there are interactions between elements of a system network structure (Saaty 1996).

Despite the fact that prioritising and weighting can be generated by other methods, ANP is found to be more appropriate for the current research because the relationships between elements appear better in a network structure. ANP is a multi-criteria decision-making tool that allows representation of any decision-making problem in a network of criteria, where interdependent relationships exist within and between all criteria. Experts' experiences are used to estimate relative magnitudes of tangible and intangible factors through paired comparisons, in order to make rational and consistent decision (Saaty 1996). ANP provides weights and priorities to these elements, taking into account the interdependent relationships among elements. However, instead of using ANP as a selection tool between alternatives, this study uses ANP as a decision tool to set priorities for project scope definition elements, based on feedback from experts.

\section{Data Collection}

\section{Approach}

The data collection was conducted through semi-structured interviews. Yin (2009) stated that semi-structured interviews can maximize the flexibility of the interview and provide the capability to shape the interview to suit individuals. The questionnaires were designed to extract information from the participants. Prior to data collection, ethics approval was sought from the Faculty of Architecture, Building and Planning Human Ethics Advisory Group at The University of Melbourne, Australia. All participants were given a plain language statement (PLS) at the start of the interview. The PLS included an invitation, research summary, what participants would be asked to do and for how long. It also addressed confidentiality issues. The participants were also asked to sign a consent form if they chose to participate.

\section{Sampling and Profile of Respondents}

A total number of 16 respondents participated in the interview. They were selected nonrandomly through the use of purposeful sampling. Participants were identified through the first author's personal contacts and by snowball sampling method; they had expertise in managing public building projects in Saudi Arabia. The majority of the respondents were either project managers or construction general managers and had over 20 years of experience in the construction industry as well as over 20 years of experience in public building projects. Also most respondents had a mixed background, which was considered to be good for this research, because it required both technical experience as well as management experience.

The interrelationships among the elements examined are complex. Thus the study uses the ANP technique. ANP is not a traditional quantitative method; instead, it is a technique in which statistical sampling is not the issue in all circumstances. In fact, seeking a large number of participants is not a necessity in ANP (Lam \& Zhao 1998). ANP is a technique in which an analytical manner of sampling is targeted, rather than a statistical one (Herath 2004; Sambasivan \& Fei 2008). The sample size (16) is sufficient for understanding the interrelationships among the elements. The participants are experts with sufficient and relevant background knowledge and experience; and their responses can be confidently relied upon; essential criteria when using the ANP technique.

Fageha, M.K \& Aibinu, A.A. 2014, 'Prioritising Project Scope Definition Elements in Public Building Projects', Australasian Journal of Construction Economics and Building, 14(3), 18-33. 


\section{Data Analysis and Results}

\section{Step One: Selection of Early Stage Scope Definition Elements}

To achieve the first objective of the study, a semi-structured interview was conducted. The PDRI for building was used as a point of departure for the data collection. Participants were presented with the list of project definition elements recommended in the PDRI for building, which includes 11 categories and 64 elements. Participants were allowed to add and delete categories and elements from the list in order to identify those that are applicable to the Saudi Arabian construction context.

The outcome gained from this step is a list of all categories and their elements that should be considered when defining a public building project in Saudi Arabia, at the pre-project planning stage. The list includes 9 categories and 42 elements, presented in Table 3 . In the data analysis, an element is included if it has been selected by two or more respondents. An element is excluded either because it is relevant to a later stage, not pre-project planning stage, or it is not applicable in the Saudi Arabian construction context.

Out of eight elements under the 'Business Strategy' category, the majority of respondents excluded one element 'Economic Analysis'. This is because public projects in Saudi Arabia are not-for-profit social infrastructure projects owned and maintained by the government and these projects serve the community needs. Public construction organisations finance their projects from the fund provided in the annual national budget specified for each project. In the process of defining the economic analysis element, specific information should be determined such as the viability of the project, evaluation of other alternatives, length of ownership and the economic impact of early or late delivery. This kind of information is not necessary in public sector projects therefore the element was excluded from the list.

In the 'Project Requirement' category, 'Value-Analysis' element was excluded, because it is relevant to the design stage of a project life cycle and not at the pre-project planning stage. The value-analysis should be in place to consider the cost effectiveness of design and material alternatives. However, at the pre-project planning stage in Saudi Arabian construction projects, the project design is not available. Additionally the architectural and engineering consultant usually provides this kind of information at the design stage of the project. Thus, element 'Value-Analysis' was excluded from list for this stage, but it still needs to be defined later by the architectural and engineering consultant at the design stage.

The 'Building Programming' category consists of thirteen elements, but only four elements 'Program Statement', 'Building Summary Space List', 'Growth and Phased Development' and 'Transportation Requirements' were included because of their relevance to the pre-project planning stage. The elements are significant at the pre-project planning stage because they form the baseline for the architectural and engineering consultant design role in subsequent stages. The remaining elements in this category were excluded because they consist of technical information too early to be defined at this stage of the project. These are more relevant to the design stage, specifically in the concept development phase.

All elements under 'Building/ Project Design Parameters' and 'Equipment' categories were excluded from the list, as they are considered technical information and relevant to later stages. Specifically 'Building/ Project Design Parameters' category is required at detailed design stage and often provided by the architectural and engineering consultants. Usually in Saudi Arabian construction projects, the 'Equipment' category is developed by the contractor and approved by the owner and the project management team.

The rest of the categories 'Owner Philosophies', 'Site Information', 'Procurement Strategy', 'Deliverables', 'Project Control' and 'Project Execution Plan' were included with all their elements because respondents recognised their importance at the pre-project planning stage. All the elements included in the list need to be defined properly at the pre-planning

Fageha, M.K \& Aibinu, A.A. 2014, 'Prioritising Project Scope Definition Elements in Public Building Projects', Australasian Journal of Construction Economics and Building, 14(3), 18-33. 
stage in order to increase the possibility of having a complete project scope definition package.

\section{Step Two: Interrelationships and Interactions among Elements}

Following the identification of elements that should be included in project scope definition at the pre-project planning stage, the next stage of the data analysis addresses the second objective of the study. This is necessary because the ANP approach requires these connections in order to formulate the structure of the network among elements. To investigate the interrelationships and interactions, a contextual relationship of 'leads to' type was chosen. This means that one element leads to another elements (Singh et al. 2003). Based on this, a contextual relationship is developed. This step is called structural selfinteraction matrix (SSIM), which is usually used in interpretive structural modelling (ISM) technique. The SSIM step can be used to indicate pair-wise relationships among variable of the system under consideration (Ahuja et al. 2009). The direction of the relation between any two elements ( $i$ and $j$ ) is assessed. Four symbols are used to indicate the type of the relation that exists between two elements as follows:

$V$ : element $i$ will help achieve element $j$ but not in both directions;

$A$ : element $j$ will help achieve element $i$ but not in both directions;

$X$ : elements $i$ and $j$ will help achieve each other; and

$O$ : elements $i$ and $j$ are unrelated.

The interrelationships and interactions among elements matrix was completed in a focus group discussion with three expert project managers. In order to complete this step, 6 sessions with 3 hours in each were required to determine 882 contextual relationships. Based on the responses, the SSIM has been developed and presented in Table 2.

Table 2: Interrelationships and interactions among elements matrix, SSIM

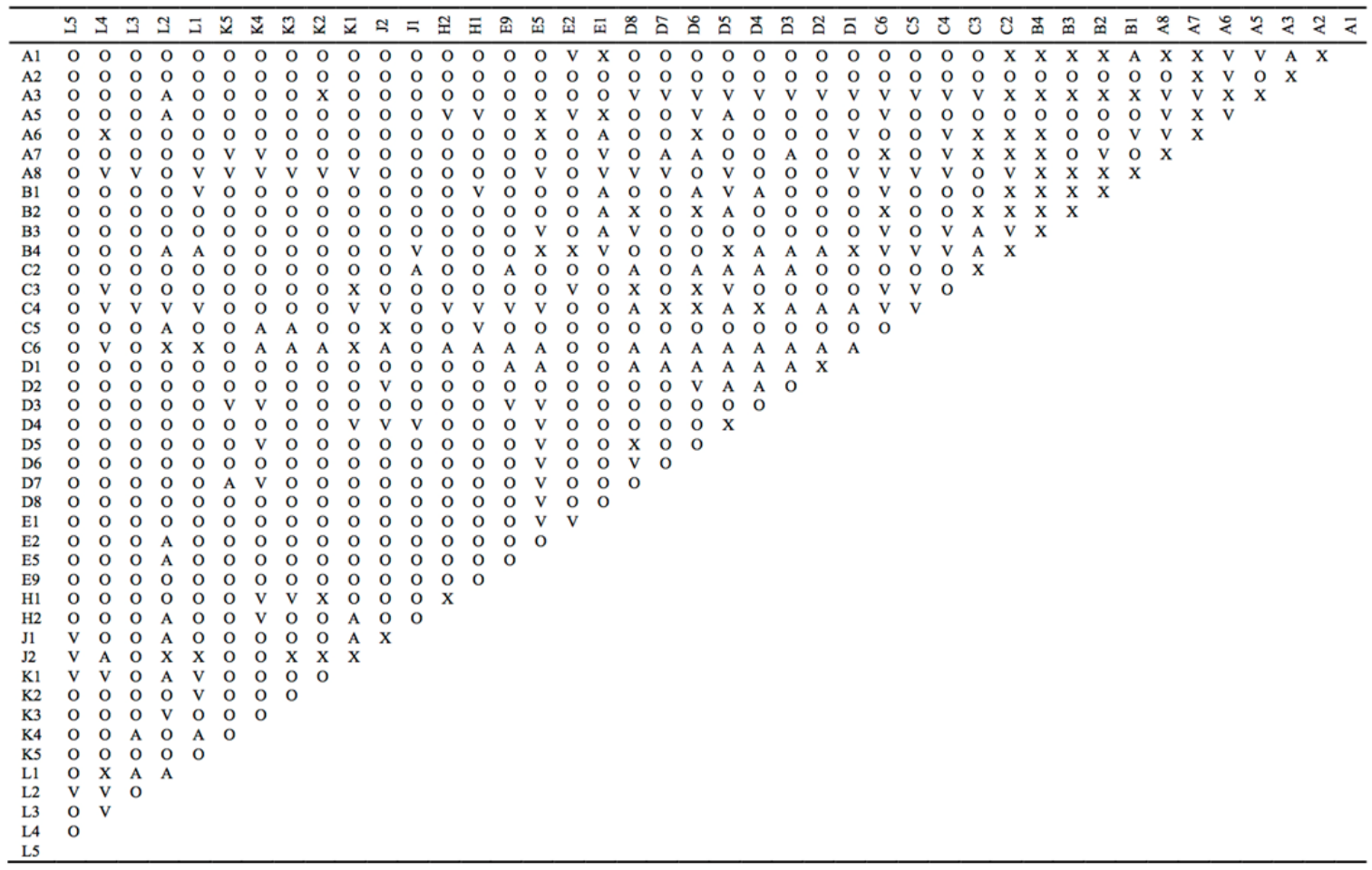

Where $V$ : element $i$ will help achieve element $j$ but not in both directions; $A$ : element $j$ will help achieve element $i$ but not in both directions; $X$ : elements $i$ and $j$ will help achieve each other; and $O$ : elements $i$ and $j$ are unrelated.

Fageha, M.K \& Aibinu, A.A. 2014, 'Prioritising Project Scope Definition Elements in Public Building Projects', Australasian Journal of Construction Economics and Building, 14(3), 18-33. 
The outcome from this step is the formulation of the network structure among the elements, which is used as an input for the ANP model in the next step. Figure 1 presents the network for the ANP step.

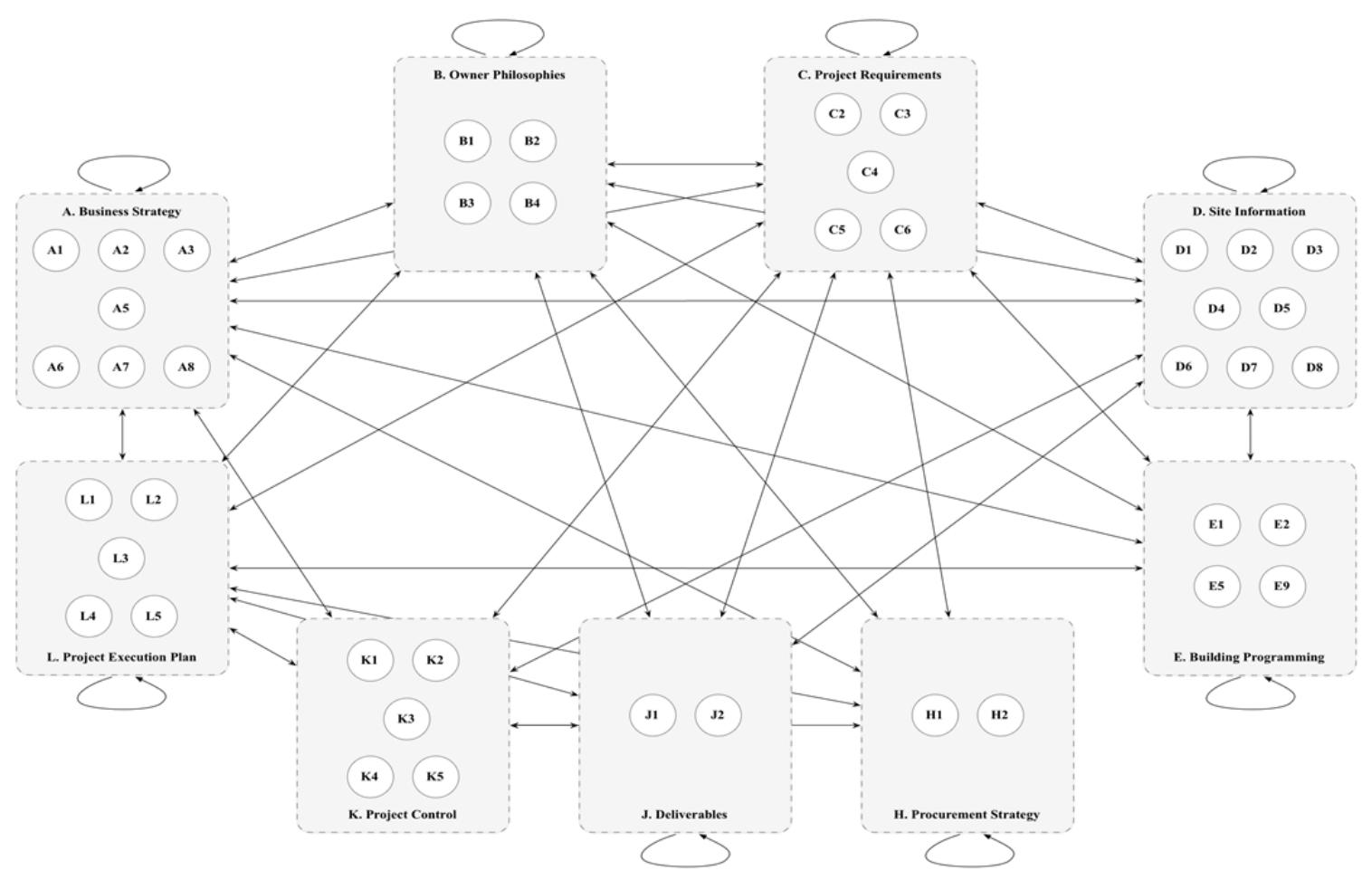

Figure 1: Interrelationships and interactions among elements, ANP model

\section{Step Three: Contribution of Elements to Overall Project Scope Definition Completeness}

The ANP was used to address the third objective of the study. Pair-wise comparisons were adopted in semi-structured interviews with the aid of structured questionnaires using the ANP model. The questionnaire was based on using the ANP model presented in Figure 1. The questionnaire included a total number of 340 pair-wise comparisons. Five project managers completed the third questionnaire based on interview sessions. They were required to answer the question that stated, 'How much importance does an element have compared to another element with respect to a preference?' In other words, participants were asked to compare between two elements and assign a score to each element in term of its importance to each other elements on the list, using Saaty's scale of judgements. The ANP uses a fundamental scale of absolute value to carry out the comparison judgements. The relative importance values were determined using a scale of 1 to 9 , where a score of 1 indicates equal importance between the two elements and 9 represents the extreme importance of the $i$ th element compared to the jth element. Participants responded to a series of pair-wise comparisons and assigned a score for all the elements to be evaluated in term of their contribution to project scope definition completeness. For example, 'with respect to element "Business Justification", the comparison was conducted in this way: please compare the relative significance between "Building Use" element and "Business Plan" element using the scale provided'. These pair-wise comparisons were conducted several times, each time with respect to an element and so on for all the relationships identified based on SSIM in the previous step. Thus, each evaluation can be represented by an eigen-vector, and the relative importance values are determined. Pair-wise comparison in ANP is performed in the 
framework of a matrix, and a local priority vector can be derived as an estimate of the relative importance associated with the elements being compared by solving the following equation:

$$
A \times w=\lambda_{\max } \times w
$$

Where $A$ is the matrix of pair-wise comparison, $w$ is the eigenvector, and $\lambda_{\max }$ is the largest eigen-value of $A$. Saaty (1980) proposed several algorithms to approximate $w$. The process of averaging over normalised columns can be done by dividing each element in a column by the sum of the column elements, and then summing the elements in each row of the resultant matrix and dividing by $n$ elements in the row. This can be deducted by:

$$
w_{i}=\frac{\sum_{i=1}^{I}\left(\frac{a_{i j}}{\sum_{j=1}^{J} a_{i j}}\right)}{J}
$$

Where $w_{i}$ is the weighted priority for component $i ; a_{i j}$ is a matrix value assigned to interdependence relationship of component $i$ to component $j$.

In this research, Super Decisions $₫$ software was used to compute the eigen-vectors from pair-wise comparison matrices. Super Decisions ${ }$, is commercially available software that has been developed for AHP and ANP. It is appropriate for solving decision problems with a hierarchy and network model (Saaty 2003). The ANP model was entered into the software and the pair-wise comparisons were calculated. The software also determined the consistency ratio (CR), which is the degree to which the pair-wise comparisons are consistent. According to Saaty (1994), people are often not consistent in their judgements. However, the recommended level of CR should be less than $5 \%$ for pair-wise comparisons between three elements, $8 \%$ for pair-wise comparisons between four elements, while for more than four elements it should be less than 10\%. A discussion about the CR was carried out with participants to inform them that their judgments in each pair-wise comparison should be consistent. Otherwise, in order to resolve the inconsistencies, some or all of their judgments for the comparisons must be repeated. The CR of each comparison in the ANP model for this research was in the acceptable range with respect to the matrix size.

Once the pair-wise comparisons were completed, the global supermatrix for project scope definition elements was generated. The overall normalised priorities were then obtained by the Super Decisions ${ }^{\circledR}$ software calculations for the supermatrix. The outcome from this ANP step, is the list of elements that are required in defining the project scope as well as their weights of importance to the scope definition completeness for a project. These weights account for the interrelationships and interactions among elements. Categories' weights were excluded from the model and the category name was the only identification for its elements, as the elements were more essential in this study. Thus, each category weight is the sum of its elements. Table 3 presents the significant weights for project scope definition elements for public building projects in Saudi Arabia.

\section{Distribution Pattern of Project Scope Definition Elements' Weights}

In the ANP analysis, the 42 elements that affect the completeness of the project scope definition package were prioritised. In this section, Pareto principle was used to investigate the distribution pattern and classify the elements into the significant few that principally contribute to project scope definition completeness, if any. Pareto analysis is a quality control tool that ranks data, in descending order from the highest frequency of occurrences to the lowest frequency of occurrences. Vilfred Pareto, an Italian economist, presented Pareto

Fageha, M.K \& Aibinu, A.A. 2014, 'Prioritising Project Scope Definition Elements in Public Building Projects', Australasian Journal of Construction Economics and Building, 14(3), 18-33. 
analysis in 1897 . He suggested that $80 \%$ of the nation's wealth was held by $20 \%$ of its population. Juran (1962) used Pareto analysis to classify the problems of quality into vital few and trivial many. In the field of construction management, Aibinu and Odeyinka (2006) used this concept and revealed that $88 \%$ of the factors were responsible for $90 \%$ of the overall construction delays.

Table 3: Significance weights for project scope definition elements

\begin{tabular}{|c|c|c|c|c|c|}
\hline & Category & & Element & $\begin{array}{l}\text { Element } \\
\text { Weight }\end{array}$ & $\begin{array}{c}\text { Total } \\
\text { Category } \\
\text { Weight }\end{array}$ \\
\hline \multirow[t]{7}{*}{ A. } & \multirow{7}{*}{$\begin{array}{l}\text { Business } \\
\text { Strategy }\end{array}$} & A1. & Building Use & 2.1173 & \\
\hline & & A2. & Business Justification & 0.3482 & \\
\hline & & A3. & Business Plan & 1.0139 & \\
\hline & & A5. & Facility Requirements & 0.7817 & \\
\hline & & A6. & Future Expansion/Alternate Consideration & 3.6373 & \\
\hline & & A7. & Site Selection Consideration & 3.3444 & \\
\hline & & A8. & Proiect Obiective Statement & 1.5962 & 12.8390 \\
\hline \multirow[t]{4}{*}{ B. } & \multirow{4}{*}{$\begin{array}{l}\text { Owner } \\
\text { Philosophies }\end{array}$} & B1. & Reliability Philosophy & 2.1463 & \\
\hline & & B2. & Maintenance Philosophy & 3.3303 & \\
\hline & & B3. & Operating Philosophy & 1.3729 & \\
\hline & & B4. & Desian Philosophy & 7.4721 & 14.3216 \\
\hline \multirow[t]{5}{*}{ C. } & \multirow{5}{*}{$\begin{array}{l}\text { Project } \\
\text { Requirements }\end{array}$} & $\mathrm{C} 2$. & Proiect Desian Criteria & 3.9751 & \\
\hline & & C3. & Evaluation of Existing Facilities & 3.3611 & \\
\hline & & C4. & Scope of Work Overview & 1.6615 & \\
\hline & & C5. & Project Schedule & 4.3799 & \\
\hline & & c6. & Proiect Cost Estimate & 7.7240 & 21.1016 \\
\hline \multirow[t]{8}{*}{ D. } & \multirow{8}{*}{$\begin{array}{l}\text { Site } \\
\text { Information }\end{array}$} & D1. & Site Layout & 3.0512 & \\
\hline & & D2. & Site Survevs & 1.0761 & \\
\hline & & D3. & Civil/Geotechnical Information & 0.0421 & \\
\hline & & D4. & Governina Requlatory Requirements & 0.3420 & \\
\hline & & D5. & Environmental Assessment & 0.9509 & \\
\hline & & D6. & Utility Sources with Supply Conditions & 1.1394 & \\
\hline & & D7. & Site Life Safety Consideration & 0.2392 & \\
\hline & & D8. & Special Water and Waste Treatment & 1.0695 & 7.9104 \\
\hline \multirow[t]{4}{*}{ E. } & \multirow{4}{*}{$\begin{array}{l}\text { Building } \\
\text { Programming }\end{array}$} & E1. & Program Statement & 1.5111 & \\
\hline & & E2. & Buildina Summary Space List & 1.1051 & \\
\hline & & E5. & Growth and Phased Development & 3.4000 & \\
\hline & & E9. & Transportation Requirements & 0.0419 & 6.0581 \\
\hline \multirow[t]{2}{*}{$\mathrm{H}$. } & \multirow{2}{*}{$\begin{array}{l}\text { Procurement } \\
\text { Strategy }\end{array}$} & $\mathrm{H} 1$. & Identify Lonq-Lead/Critical Equip. and & 3.9120 & \\
\hline & & $\mathrm{H} 2$. & Procurement Procedures and Plans & 2.5827 & 6.4947 \\
\hline \multirow[t]{2}{*}{ J. } & \multirow[t]{2}{*}{ Deliverables } & J1. & CADD/Model Requirements & 3.4492 & \\
\hline & & J2. & Documentation/Deliverables & 7.6478 & 11.0970 \\
\hline \multirow[t]{5}{*}{$\mathrm{K}}$. & \multirow{5}{*}{$\begin{array}{l}\text { Project } \\
\text { Control }\end{array}$} & K1. & Project Quality Assurance and Control & 3.6561 & \\
\hline & & K2. & Project Cost Control & 0.4982 & \\
\hline & & K3. & Proiect Schedule Control & 2.1833 & \\
\hline & & K4. & Risk Manaqement & 2.7012 & \\
\hline & & K5. & Safety Procedures & 0.1472 & 9.1860 \\
\hline \multirow[t]{6}{*}{ L. } & Project & L1. & Proiect Orqanisation & 2.9268 & \\
\hline & Execution & L2. & Owner Approval Requirements & 1.5570 & \\
\hline & \multirow[t]{3}{*}{ Plan } & L3. & Proiect Delivery Method & 0.1117 & \\
\hline & & L4. & Design/Construction Plan \& Approach & 3.6221 & \\
\hline & & L5. & Substantial Completion Requirements & 2.7740 & 10.9916 \\
\hline & Total & & & 100 & 100 \\
\hline
\end{tabular}

Fageha, M.K \& Aibinu, A.A. 2014, 'Prioritising Project Scope Definition Elements in Public Building Projects', Australasian Journal of Construction Economics and Building, 14(3), 18-33. 
Table 4: Pareto analysis of project scope definition elements

\begin{tabular}{|c|c|c|c|c|c|}
\hline Rank & & Elements & $\begin{array}{c}\text { Cumulative } \\
\text { number of } \\
\text { elements \% }\end{array}$ & $\begin{array}{c}\text { ANP } \\
\text { Weight \% }\end{array}$ & $\begin{array}{c}\text { Cumulative } \\
\text { ANP weight } \\
\%\end{array}$ \\
\hline 1 & C6 & Project Cost Estimate & 2.38 & 7.72 & 7.72 \\
\hline 2 & $\mathrm{~J} 2$ & Documentation/Deliverables & 4.76 & 7.65 & 15.37 \\
\hline 3 & B4 & Design Philosophy & 7.14 & 7.47 & 22.84 \\
\hline 4 & $\mathrm{C} 5$ & Project Schedule & 9.52 & 4.38 & 27.22 \\
\hline 5 & $\mathrm{C} 2$ & Project Design Criteria & 11.90 & 3.98 & 31.20 \\
\hline 6 & $\mathrm{H} 1$ & $\begin{array}{l}\text { Identify Long-Lead/Critical Equip. \& } \\
\text { Materials }\end{array}$ & 14.29 & 3.91 & 35.11 \\
\hline 7 & K1 & Project Quality Assurance and Control & 16.67 & 3.66 & 38.77 \\
\hline 8 & A6 & Future Expansion/Alternate & 19.05 & 3.64 & 42.40 \\
\hline 9 & L4 & Design/Construction Plan \& Approach & 21.43 & 3.62 & 46.03 \\
\hline 10 & $\mathrm{~J} 1$ & CADD/Model Requirements & 23.81 & 3.45 & 49.48 \\
\hline 11 & E5 & Growth and Phased Development & 26.19 & 3.40 & 52.88 \\
\hline 12 & $\mathrm{C} 3$ & Evaluation of Existing Facilities & 28.57 & 3.36 & 56.24 \\
\hline 13 & A7 & Site Selection Consideration & 30.95 & 3.34 & 59.58 \\
\hline 14 & B2 & Maintenance Philosophy & 33.33 & 3.33 & 62.91 \\
\hline 15 & D1 & Site Layout & 35.71 & 3.05 & 65.96 \\
\hline 16 & L1 & Project Organisation & 38.10 & 2.93 & 68.89 \\
\hline 17 & L5 & Substantial Completion Requirements & 40.47 & 2.77 & 71.66 \\
\hline 18 & K4 & Risk Management & 42.85 & 2.70 & 74.36 \\
\hline 19 & $\mathrm{H} 2$ & Procurement Procedures and Plans & 45.24 & 2.58 & 76.95 \\
\hline 20 & K3 & Project Schedule Control & 47.62 & 2.18 & 79.13 \\
\hline 21 & B1 & Reliability Philosophy & 50.00 & 2.15 & 81.28 \\
\hline 22 & A1 & Building Use & 52.38 & 2.12 & 83.39 \\
\hline 23 & $\mathrm{C} 4$ & Scope of Work Overview & 54.76 & 1.66 & 85.06 \\
\hline 24 & A8 & Project Objective Statement & 57.14 & 1.60 & 86.65 \\
\hline 25 & L2 & Owner Approval Requirements & 59.52 & 1.56 & 88.21 \\
\hline 26 & E1 & Program Statement & 61.90 & 1.51 & 89.72 \\
\hline 27 & B3 & Operating Philosophy & 64.28 & 1.37 & 91.09 \\
\hline 28 & D6 & Utility Sources with Supply Conditions & 66.66 & 1.14 & 92.23 \\
\hline 29 & E2 & Building Summary Space List & 69.04 & 1.11 & 93.34 \\
\hline 30 & $\mathrm{D} 2$ & Site Surveys & 71.42 & 1.08 & 94.41 \\
\hline 31 & D8 & $\begin{array}{l}\text { Special Water \& Waste Treatment } \\
\text { Requirements }\end{array}$ & 73.81 & 1.07 & 95.48 \\
\hline 32 & A3 & Business Plan & 76.19 & 1.01 & 96.50 \\
\hline 33 & D5 & Environmental Assessment & 78.57 & 0.95 & 97.45 \\
\hline 34 & A5 & Facility Requirements & 80.95 & 0.78 & 98.23 \\
\hline 35 & K2 & Project Cost Control & 83.33 & 0.50 & 98.73 \\
\hline 36 & A2 & Business Justification & 85.71 & 0.35 & 99.08 \\
\hline 37 & D4 & Governing Requlatory Requirements & 88.10 & 0.34 & 99.42 \\
\hline 38 & D7 & Site Life Safety Consideration & 90.48 & 0.24 & 99.66 \\
\hline 39 & K5 & Safety Procedures & 92.86 & 0.15 & 99.80 \\
\hline 40 & L3 & Project Delivery Method & 95.24 & 0.11 & 99.92 \\
\hline 41 & D3 & Civil/Geotechnical Information & 97.62 & 0.04 & 99.96 \\
\hline 42 & E9 & Transportation Requirements & 100.00 & 0.04 & 100.00 \\
\hline
\end{tabular}

Drawing on the Pareto principle, this research conducted an analysis of the distribution pattern of the 42 projects scope definition elements, in order to possibly identify the trivial and important elements. The relative average weights were computed based on the ANP

Fageha, M.K \& Aibinu, A.A. 2014, 'Prioritising Project Scope Definition Elements in Public Building Projects', Australasian Journal of Construction Economics and Building, 14(3), 18-33. 
results in Table 3 and equated to 1. Table 4 shows the result of Pareto analysis and Figure 2 illustrates it.

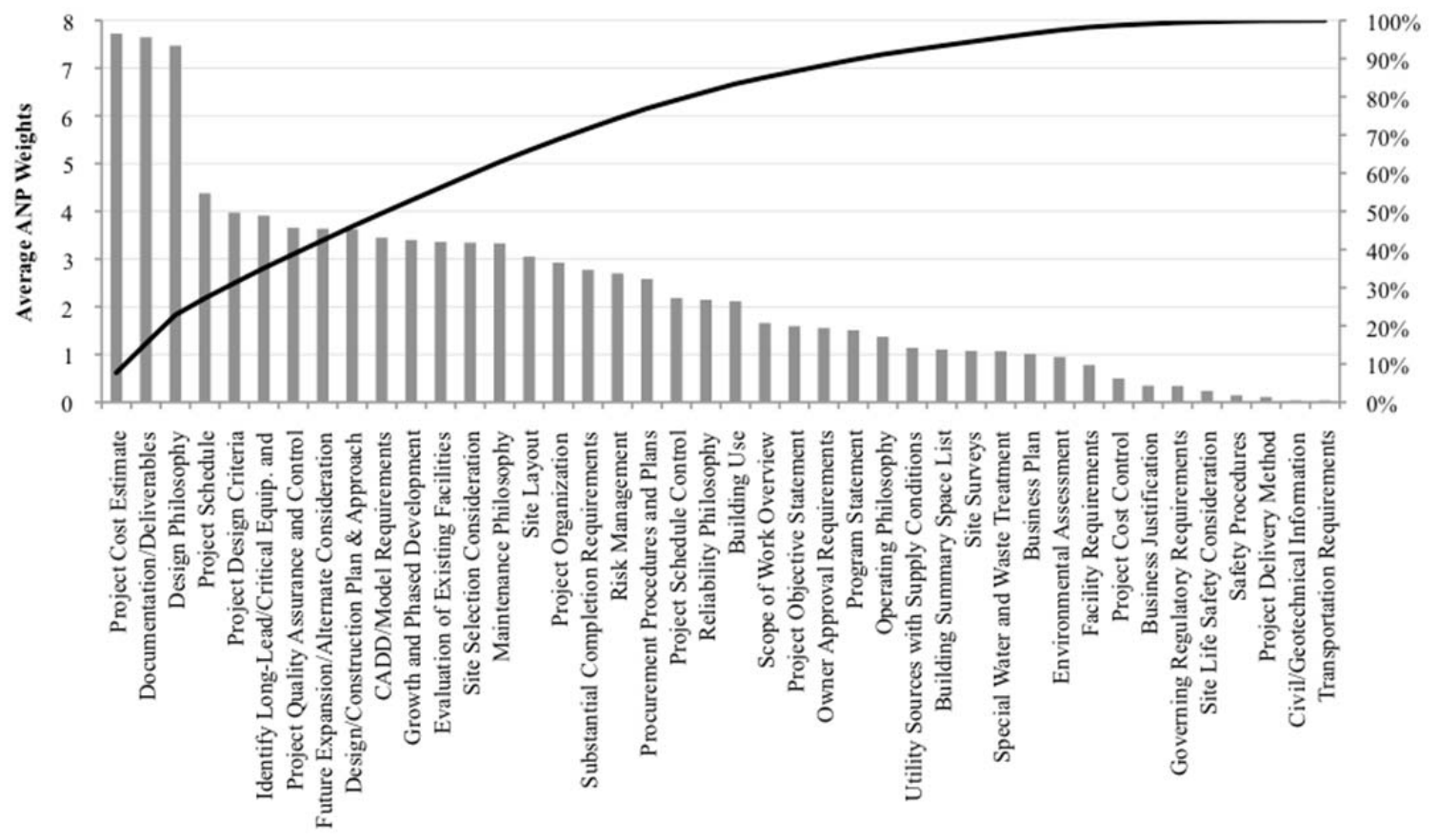

Figure 2: Pareto analysis of project scope definition elements

The result of Pareto analysis on the project scope definition elements revealed that $80.95 \%$ of the elements, that is 34 highest priority elements, contribute $98.23 \%$ of all elements' weights. More than $80 \%$ of the identified project scope definition elements are responsible for about $98 \%$ of the completeness of the project scope definition document. However, about $7 \%$ of the elements, that is the 3 highest priority elements, are the single largest contributors to the total weights. The three elements contributed $22.84 \%$ of all project scope definition elements' weights for the completeness.

\section{Discussion of Results}

Looking at the contribution of each element to the overall project scope definition completeness (indicated by the weight), as presented in Table 4, the most influential element for project scope definition completeness is the 'Project Cost Estimate', weighing $7.72 \%$. This is not surprising because the reason for cost overrun challenges during a project's execution is often inaccurate estimates. Inadequate or unclear cost estimation for every single direct and indirect item in a project affects the cost performance during the implementation stage and can lead to delays, cost overruns, schedule overruns, and project failure due to lack of finance. Additionally, in order for Saudi Arabian public construction organisations to be able to finance their projects, they need to present a clear and detailed cost estimation document for the project in the annual national budget. This is because each year the government of Saudi Arabia announces the annual national budget together with the share for each ministry including construction related organisations. In defining the project cost estimate element, all costs necessary for completion of the project should be addressed. It may include 
information such as: construction contract estimate, architectural and engineering consultants fees, administrative costs, insurance requirements, utility costs during construction and all technical information related to the site and the project.

The second most influential element is the 'Documentation and Deliverables' weighing 7.65\%. Documentation and deliverables are required during the project execution and must be identified in pre-project planning in order to avoid uncertainty and rework during execution. They are also important during project execution and after completion for best practice benchmarking. Deliverables may include all drawings and specifications, project correspondence, permits, quality assurance documents, warranties, working drawings, maintenance and operation information.

Project 'Design Philosophy', weighing $12.84 \%$, is the third most influential element. In accordance with the project functionality and environments, a listing of the design philosophy issues should be developed. This listing may include design life, aesthetic requirements, quality of life, sustainability, levels of certification, and requirements of any adopted antiterrorism design standards. This information is necessary at the pre-project planning stage before commencing the design stage in order to avoid major changes and rework. Even though all project scope definition elements are very significant for planning the project, some of the elements have low contribution weights in relation to the completeness of the project scope definition package. This is because these elements may be defined briefly at the planning stage, and then in more detail at later stages of the projects' development cycle.

When comparing the result of project scope definition elements' weights in this study with PDRI elements' weights, some differences are evident. The list provided in this study includes 42 elements instead of the 64 elements included in the PDRl's list. 'Building Use' element is the most influential element in the PDRI for building whereas in this study it occurs after $50 \%$ of all elements, which is the $22^{\text {nd }}$ element in the prioritised list. The reason is that the PDRI is a generalised tool for all building types regardless of whether they are public or private projects. Therefore, it is vital to know the use and type of the building because this could affect other scope definition elements. This study focuses on public building projects, which usually are facility services projects, thus this could account for the differences in the importance of 'Building Use' in the PDRI list.

Unexpectedly, this study discovered that 'Facility Requirements' element is within the lowest 10 influential elements. In contrast, it is the second influential element in PDRI. The reason behind this deviation is that respondents consider this element as a technical issue, which is discussed briefly in pre-project planning stage and in more detail in the design stage. This practice is one of the reasons for uncertainties and can lead to project delays and incomplete projects.

Element 'Project Cost Estimate' is significant in both PDRI and this study. It is the primary contributor element to the completeness of project scope definition in this study and ranked the $4^{\text {th }}$ contributor element in the PDRI for building.

Element 'Architectural Design' is within the highest 10 contributors to the project scope definition completeness. Conversely, it was excluded from the list in this study. This study is limited to the pre-project planning stage of the project life cycle. Similarly to all the other elements of the 'Building/ Project Design Parameters' category, architectural design at this stage has not yet been developed. Usually the building/project design parameters are provided at the design stage by the architectural and engineering consultants.

The second most influential element in this study is 'Documentation and Deliverables' and the $10^{\text {th }}$ element is 'CADD/Model Requirements'. However, in the PDRI, these occur as the lowest three elements contributing to scope definition completeness.

Fageha, M.K \& Aibinu, A.A. 2014, 'Prioritising Project Scope Definition Elements in Public Building Projects', Australasian Journal of Construction Economics and Building, 14(3), 18-33. 


\section{Summary of Findings}

Compared to industrialised countries, Saudi Arabia is less developed and the challenges are certainly different. There is a noticeable lack of research on the knowledge required to define project scope in Saudi's construction context. Therefore, this research identifies 9 categories including 42 elements that should be identified and evaluated at the pre-project planning stage in public construction projects in Saudi Arabia. Also it identifies the elements' relative significant weights for the project scope definition document completeness with respect to the interrelationship and interactions among them.

The result from Pareto analysis on the elements revealed that there is no discernable difference between the 42 elements except the three highest elements. The analysis shows that more than $80 \%$ of the elements are responsible for about $98 \%$ of the completeness, which indicates that all the elements are important for ensuring the project scope definition completeness, thus enhancing the likelihood of achieving better project outcomes. An inspection of the elements indicates that the 34 highest priority project scope definition elements is a combination from all the nine categories. This suggests that even though the project scope definition elements can be prioritised, the contribution of all the nine categories to the overall scope definition completeness is not negligible. The result implies that all the categories are important for ensuring project scope definition completeness.

Even though construction projects may share the same procedures globally, the PDRI is a good approach for evaluating the completeness of project scope definition. The PDRI was developed in the US mainly for the US construction context. Therefore, it is necessary to identify a different set of information that respects the nature and the environment of a project's context.

\section{Conclusion}

The developed priorities list is useful as it can guide decision-makers in evaluating project scope definition completeness and deciding whether to proceed with a project or not. In other words, the project management team can measure the level of each project scope definition completeness element by using a Likert scale of satisfaction as follows: Incomplete or Poor Definition (0\%), Major Deficiencies (25\%), Some Deficiencies (50\%), Minor Deficiencies (75\%) and Complete Definition (100\%). Then all scores are calculated according to each element priority weight, presented in Table 3. The final score of the level of project scope definition completeness would be the total of all the elements scores. The higher the total score the more well defined the project is. This procedure allows project management teams to take actions that can help improve the scope definition of those elements that have low scores, which indicate the area of risk to the project, and maximize the chance for a successful project.

The ANP is an innovative tool for multi-criteria decision-making. Both researchers and industry practitioners should find it useful in different ways. Most of the data obtained for the ANP were obtained from an expert panel, and potentially can be analytically generalised. Even though the technique does not require a large sample size, increasing the sample size could improve the result. In addition, although the study focuses on public building projects only in Saudi Arabia, the results are applicable to other developing countries with similar environments of delivery methods and industry practices. The study can be replicated in the context of private sector projects.

Fageha, M.K \& Aibinu, A.A. 2014, 'Prioritising Project Scope Definition Elements in Public Building Projects', Australasian Journal of Construction Economics and Building, 14(3), 18-33. 


\section{References}

Abdul-Hadi, N, Al-Sudairi, A.S. \& Alqahtani, S. 2005, 'Prioritizing barriers to successful business process re-engineering (BPR) efforts in Saudi Arabian construction industry', Construction Management and Economics, 23 (3), 305-315.

Ahuja, V, Yang, J. \& Shankar, R. 2009, 'Benefits of collaborative ICT adoption for building project management', Construction Innovation: Information, Process, Management, 9 (3), 323-340.

Aibinu, A.A. \& Odeyinka, H.A. 2006, 'Construction delays and their causative factors in Nigeria', Journal of Construction Engineering and Management, 132 (7), 667-677.

Al-Humaidan, M. 2011, Al-Eqtisadiah, Online. Available:

http://www.aleqt.com/2011/12/09/article_605385.html. Accessed 09-12-2011.

Al-Khalil, M.I. \& Al-Ghafly, M.A. 1999, 'Delay in public utility projects in Saudi Arabia', International Journal of Project Management, 17 (2), 101-106.

Al-Kharashi, A. \& Skitmore, M. 2009. 'Causes of delays in Saudi Arabian public sector construction projects', Construction Management and Economics, 27 (1), 3-23.

Alsehaimi, A, Koskela, L. \& Tzortzopoulos, P. 2013, 'Need for Alternative Research Approaches in Construction Management: Case of Delay Studies', Journal of Management in Engineering, 29 (4), 407-413.

Arain, F.M, Pheng, L.S. \& Assaf, S.A. 2006, 'Contractors' views of the potential causes of inconsistencies between design and construction in Saudi Arabia', Journal of Performance of Constructed Facilities, 20 (1), 74-83.

Assaf, S.A. \& Al-Hejji, S. 2006, 'Causes of delay in large construction projects', International Journal of Project Management, 24 (4), 349-357.

Atkinson, R, Crawford, L. \& Ward, S. 2006, 'Fundamental uncertainties in projects and the scope of project management', International Journal of Project Management, 24 (8), 687.

Cano, J.L. \& LidóN, I. 2011, 'Guided reflection on project definition', International Journal of Project Management.

Central Department of Information and Statistics, 2013, National Accounts Indicators 2013, Online. Available: http://www.cdsi.gov.sa/dmdoc/nat-2013.pdf.

Cheng, E.W. \& Li, H. 2001, 'Analytic hierarchy process: an approach to determine measures for business performance', Measuring Business Excellence, 5 (3), 30-37.

Cho, C.S. \& Gibson, E. 2001. 'Building project scope definition using project definition rating index', Journal of Architectural Engineering, 7 (4), 115.

Chritamara, S, Ogunlana, S.O. \& Bach, N.L. 2001, 'Investigating the effect of initial scope establishment on the performance of a project through system dynamics modelling', Engineering Construction and Architectural Management, 8 (5-6), 381.

Cii 1994, Pre-project planning: Beginning a project the right way, Construction Industry Institute, The University of Texas at Austin.

Gibson, G.E, Kaczmarowski, J. \& Lore Jr, H. 1995, 'Preproject-planning process for capital facilities', Journal of Construction Engineering and Management, 121-312.

Gibson, G.E, Wang, Y.R, Cho, C.S. \& Pappas, M.P. 2006, 'What Is Preproject Planning, Anyway?', Journal of Management in Engineering, 22-35.

Haponava, T. \& Al-Jibouri, S. 2009, 'Identifying key performance indicators for use in control of preproject stage process in construction', The International Journal of Productivity and Performance Management, 58 (2), 160.

Hatush, Z. \& Skitmore, M. 1998, 'Contractor selection using multicriteria utility theory: an additive model', Building and Environment, 33 (2), 105-115.

Herath, G. 2004, 'Incorporating community objectives in improved wetland management: the use of the analytic hierarchy process', Journal of Environmental Management, 70 (3), 263-273.

Fageha, M.K \& Aibinu, A.A. 2014, 'Prioritising Project Scope Definition Elements in Public Building Projects', Australasian Journal of Construction Economics and Building, 14(3), 18-33. 
Hwang, B.G, Thomas, S.R, Haas, C.T. \& Caldas, C.H. 2009, 'Measuring the impact of rework on construction cost performance', Journal of Construction Engineering and Management, 135-187.

Juran, J.M. 1962, 'Quality control handbook', New York, McGraw-Hill.

Kähkönen, K. 1999, 'Multi-character model of the construction project definition process', Automation in Construction, 8 (6), 625.

Lam, K. \& Zhao, X. 1998, 'An application of quality function deployment to improve the quality of teaching', International Journal of Quality \& Reliability Management, 15 (4), 389-413.

Lordsleem Jr, A.C. \& Melhado, S.B. 2014, 'Scope of design for production of wall partitions', Journal of Engineering, Design and Technology, 12 (2), 263-279.

Love, P.E.D. 2002, 'Influence of project type and procurement method on rework costs in building construction projects', Journal of Construction Engineering and Management, 128(1), 18-29.

Love, P.E.D, Irani, Z. \& Edwards, D.J. 2004, 'A rework reduction model for construction projects', Engineering Management, IEEE Transactions on, 51 (4), 426-440.

Mirza, M.N, Pourzolfaghar, Z. \& Shahnazari, M. 2013, 'Significance of Scope in Project Success', Procedia Technology, 9 (2013), 722-729.

Saaty, R.W. 2003, 'Decision making in complex environments', Pittsburgh, Creative Decisions Foundation.

Saaty, T.L. 1980, The analytic hierarchy process: planning, priority setting, resources allocation

Saaty, T.L. 1994, 'How to make a decision: the analytic hierarchy process', Interfaces, 19-43

Saaty, T.L. 1996, Decision Making with Dependence and Feedback: The Analytic Network Process, Pittsburgh, RWS Publications.

Sambasivan, M. \& Fei, N.Y. 2008, 'Evaluation of critical success factors of implementation of ISO 14001 using analytic hierarchy process (AHP): a case study from Malaysia', Journal of Cleaner Production, 16 (13), 1424-1433.

Singh, M, Shankar, R, Narain, R. \& Agarwal, A. 2003, 'An interpretive structural modeling of knowledge management in engineering industries', Journal of Advances in Management Research, 1 (1), 28-40.

Wang, Y.R. 2002, 'Applying The PDRI in Project Risk Management', Ph.D Thesis, University of Texas at Austin, Texas.

Wang, Y.R. \& Gibson, E. 2010, 'A study of preproject planning and project success using ANNs and regression models', Automation in Construction, 19 (3), 341-346.

Woodhead, R.M. 2000, 'Investigation of the early stages of project formulation', Facilities, 18 (13/14), 524-534.

Yin, R.K. 2009, Case study research: Design and methods, $4^{\text {th }}$ ed., Los Angeles, Sage publications, INC. 